\section{Nodulation and Plant Growth of Shepherdia Xutahensis 'Torrey' Topdressed with Controlled-release Fertilizer}

\author{
Ji-Jhong Chen \\ Department of Plants, Soils, and Climate, Utah State University, 4820 Old \\ Main Hill, Logan, UT 84322
}

Heidi Kratsch

University of Nevada, Reno Extension, 4955 Energy Way, Reno, NV 89502

Jeanette Norton, Youping Sun, and Larry Rupp

Department of Plants, Soils, and Climate, Utah State University, 4820 Old Main Hill, Logan, UT 84322

Additional index words. actinorhizal plant, Frankia, Shepherdia, root nodule, sustainable landscape

Abstract. Shepherdia $\times$ utahensis 'Torrey' ('Torrey' hybrid buffaloberry) is an actinorhizal plant that can fix atmospheric nitrogen $\left(\mathrm{N}_{2}\right)$ in symbiotic root nodules with Frankia. Actinorhizal plants with $\mathbf{N}_{2}$-fixing capacity are valuable in sustainable nursery production and urban landscape use. However, whether nodule formation occurs in $S$. $\times$ utahensis 'Torrey' and its interaction with nitrogen $(N)$ fertilization remain largely unknown. Increased mineral $\mathbf{N}$ in fertilizer or nutrient solution might inhibit nodulation and lead to excessive $\mathrm{N}$ leaching. In this study, $S$. $\times$ utahensis 'Torrey' plants inoculated with soils containing Frankia were irrigated with an $\mathrm{N}$-free nutrient solution with or without added $2 \mathrm{~mm}$ ammonium nitrate $\left(\mathrm{NH}_{4} \mathrm{NO}_{3}\right)$ or with 0.0 to $8.4 \mathrm{~g} \cdot \mathrm{L}^{-1}$ controlled-release fertilizer (CRF; $15 \mathrm{~N}-3.9 \mathrm{P}-10 \mathrm{~K})$ to study nodulation and plant morphological and physiological responses. The performance of inoculated plants treated with various amounts of CRF was compared with uninoculated plants treated with the manufacturer's prescribed rate. Plant growth, gas exchange parameters, and shoot $N$ content increased quadratically or linearly along with increasing CRF application rates (all $P<0.01$ ). No parameters increased significantly at CRF doses greater than $2.1 \mathrm{~g} \cdot \mathrm{L}^{-1}$. Furthermore, the number of nodules per plant decreased quadratically $(P=0.0001)$ with increasing $C R F$ application rates and nodule formation were completely inhibited at $2.9 \mathrm{~g} \cdot \mathrm{L}^{-1} \mathrm{CRF}$ or by $\mathrm{NH}_{4} \mathrm{NO}_{3}$ at $2 \mathrm{mM}$. According to our results, nodulation of $S$. $\times$ utahensis 'Torrey' was sensitive to $\mathrm{N}$ in the nutrient solution or in increasing CRF levels. Furthermore, plant growth, number of shoots, leaf area, leaf dry weight, stem dry weight, root dry weight, and $N$ content of shoots of inoculated $S$. Xutahensis 'Torrey' plants treated with $2.1 \mathrm{~g} \cdot \mathrm{L}^{-1} \mathrm{CRF}$ were similar to those of uninoculated plants treated with the manufacturer's prescribed rate. Our results show that $S$. $\times$ utahensis 'Torrey' plants inoculated with soil containing Frankia need less CRF than the prescribed rate to maintain plant quality, promote nodulation for $\mathrm{N}_{2}$ fixation, and reduce $\mathrm{N}$ leaching.

Nursery production of native plants has increased tremendously because of increasing interest in using native plants in urban gardens and landscapes (Thomas and Schrock, 2004). The growing interest in native plants is attributable to their ornamental potential, including aesthetic appearance, bio-diversity, and, most importantly, water conservation (Hooper et al., 2008). In the Intermountain West, native plants are used in low-water-use landscapes with sustainable and low-water-use features (Mee et al., 2003). However, it is difficult to establish native plants in disturbed and poorly drained soils (Edmondson et al., 2011; Mee et al., 2003). Native plants in the Intermountain West, such as Arctostaphylos patula (greenleaf manzanita), Artemisia nova (black sagebrush), Ceratoides rounded form and outstanding drought tolerance, but it is highly sensitive to excessive landscape irrigation (Sriladda, 2011; Sriladda et al., 2014). However, $S$. argentea is a fastgrowing, deciduous shrub that adapts to a wide range of soil conditions, but it is less aesthetically acceptable due to its thorny and unkempt appearance (Sriladda et al., 2016). To enhance the adaptability of Shepherdia to wet and poorly drained soils while maintaining drought tolerance and aesthetic appearance, $S$. ×utahensis Torrey, an interspecific hybrid cultivar of $S$. argentea and $S$. rotundifolia, was created by Sriladda et al. (2016). This hybrid cultivar has the potential for use in low-water landscapes because of its tolerance to drought conditions as well as the occasionally wet soils found in residential landscape environments (Sriladda et al., 2016). Furthermore, S. argentea and S. rotundifolia are actinorhizal plants (Benson and Silvester, 1993), and $S$ ×utahensis 'Torrey' can form a symbiotic association with Frankia to fix $\mathrm{N}_{2}$ in its root nodules (J. Chen, unpublished data). This biological $\mathrm{N}_{2}$-fixing capacity may reduce the need for nitrogenous fertilization of nodulated actinorhizal plants, thus solving two primary concerns in the nursery industry: mineral $\mathrm{N}$ runoff and leaching to groundwater (Urbano, 1989). For example, nodulated Alnus maritima (seaside alder) had better fertilizer use efficiency when inoculated with soils containing Frankia than uninoculated plants (Beddes and Kratsch, 2010). In another study, Frankia-induced nodulation improved plant performance and $\mathrm{N}$ use efficiency of Alnus incana (gray alder) (Sellstedt and Huss-Danell, 1986). Laws and Graves (2005) reported that nodulated $A$. maritima sustained plant vigor and quality with a lower $\mathrm{NH}_{4} \mathrm{NO}_{3}$ concentration than uninoculated plants. Therefore, actinorhizal plants with symbiotic nodules have commercial potential in nursery production and urban landscapes (Kratsch and Graves, 2004).

Slow-release fertilizer and CRF gradually deliver mineral nutrients (mainly $\mathrm{N}$ ) to plants and have been widely used in nursery production (Adams et al., 2013; Beddes and Kratsch, 2010), but excessive $\mathrm{N}$ fertilization reduces nodule formation of actinorhizal plants inoculated with Frankia (HussDanell, 1997). For example, A. maritima exhibited a decreased nodule number when $\mathrm{NH}_{4} \mathrm{NO}_{3}$ increased from 0 to $8.0 \mathrm{~mm}$ (Laws and Graves, 2005). In addition, Beddes and Kratsch (2010) reported that A. maritima plants had a decreased nodule number when CRF $(15 \mathrm{~N}-3.9 \mathrm{P}-10 \mathrm{~K})$ levels increased from 0 to $1.8 \mathrm{~g} \cdot \mathrm{L}^{-1}$, and $3.6 \mathrm{~g} \cdot \mathrm{L}^{-1}$ completely inhibited nodule formation. Unfortunately, although $\mathrm{N}$ fertilization significantly influences nodule formation, the impact of fertilizers on plant growth and nodule development of $S$. Xutahensis 'Torrey' is largely unknown. Research investigating the effects of CRF and its application rate on nodulation is needed to inform best practices for nurseries.

The objectives of this research were to 1 ) investigate the impacts of $\mathrm{NH}_{4} \mathrm{NO}_{3}$ and $\mathrm{CRF}$ on nodule number and plant growth of 
S. ×utahensis 'Torrey', and 2) to determine CRF application rates that maintain acceptable plant quality with minimal nitratenitrogen $\left(\mathrm{NO}_{3}-\mathrm{N}\right)$ leaching. In addition, the effects of inoculation on growth and gas exchange parameters were studied by comparing inoculated $S$. ×utahensis 'Torrey' plants treated with 0 to $8.4 \mathrm{~g} \cdot \mathrm{L}^{-1} \mathrm{CRF}$ with uninoculated plants treated with the manufacturer's prescribed rate of $3.2 \mathrm{~g} \cdot \mathrm{L}^{-1}$.

\section{Materials and Methods}

Shepherdia ×utahensis 'Torrey' plants were clonally propagated using cuttings collected from the Utah State University Greenville Research Farm (North Logan, UT) on 16 July 2019. Except for the two to three pairs of leaves at the top, leaves were removed from cuttings. Cuttings were dipped in $1000 \mathrm{mg} \cdot \mathrm{L}^{-1}$ indole-3-butyric acid (Hormodin 1; OHP, Mainland, PA) and placed in a tray filled with perlite (Hess Perlite, Malad City, ID). Trays were kept on a mist bench in a greenhouse with temperatures set at $25 / 20^{\circ} \mathrm{C}$ (day/night). On 1 Oct. 2019, nodule-free rooted cuttings were transplanted into 3.8-L injection-molded, polypropylene containers (PC1D-4; Nursery Supplies, Orange, CA) filled with calcined clay (Turface MVP; Profile Products, Buffalo Grove, IL), which is an inorganic growing substrate that is used for native plants (Beddes and Kratsch, 2009). Plants were irrigated with deionized water before the experiment.

On 15 Oct. 2019, the experiment was initiated and plants of uniform size were randomly assigned to 12 groups. In previous studies, soil collected from the rhizosphere of an actinorhizal plant was used as a source of Frankia inocula (Tortosa and Cusato, 1991). In this study, field soils $(\approx 8 \mathrm{~L})$ were collected from the rhizosphere of a $S$. ×utahensis 'Torrey' plant (lat. $41^{\circ} 45^{\prime} \mathrm{N}$, long. $111^{\circ} 48^{\prime}$ W) at Utah State University Greenville

Received for publication 26 June 2020. Accepted for publication 25 Sept. 2020.

Published online 5 November 2020.

This research was supported in part by the United States Department of Agriculture (USDA) National Institute of Food and Agriculture (NIFA) Hatch project UTA01381, New Faculty Start-Up Funds from the Utah State University Office of Research and Graduate Studies, and the Center for Water-Efficient Landscaping. It was approved as the UAES journal paper number 9359 . We are grateful for valuable comments from anonymous reviewers. The content is solely the responsibility of the authors and does not necessarily represent the official views of the funding agencies. Mention of a trademark, proprietary product, or vendor does not constitute a guarantee or warranty of the product by the USDA or the American Society for Horticultural Science and does not imply its approval to the exclusion of other products or vendors that also may be suitable.

Y.S. and J.C. are the corresponding authors E-mail: youping.sun@usu.edu or jijhong.chen@ gmail.com.

This is an open access article distributed under the $\mathrm{CC}$ BY-NC-ND license (https://creativecommons.org/ licenses/by-nc-nd/4.0/).
Research Farm. Plants in groups 1 to 10 were inoculated with $50 \mathrm{~mL}$ of field soil layered on the surface of the substrate. For groups 1 to 8 , each plant was topdressed with $0,0.5,1.0$, 2.0, 4.0, 8.0, 16.0, and $32.0 \mathrm{~g}$ of Osmocote 15N-3.9P-10K (Osmocote Plus 15-9-12; Israel Chemicals, Tel Aviv-Yafo, Israel, hereafter referred to as $\mathrm{CRF}$ ), resulting in CRF levels of $0,0.1,0.3 .0 .5,1.1,2.1,4.2$, and $8.4 \mathrm{~g} \cdot \mathrm{L}^{-1}$, respectively. Plants in groups 9 and 10 were irrigated with $500 \mathrm{~mL}$ modified $\mathrm{N}$-free nutrient solution (Bugbee, 2004) supplemented with (N-supplement) or without (N-lacking), respectively, added $2 \mathrm{mM} \mathrm{NH}_{4} \mathrm{NO}_{3}$ at $\mathrm{pH} 7.5$ every other day, resulting in $\mathrm{NO}_{3}-\mathrm{N}$ concentrations of $114.9 \pm 6.8$ and $13.0 \pm 1.1$ $\mathrm{mg} \cdot \mathrm{L}^{-1}$ (mean $\pm \mathrm{SE}$ ), respectively. Plants in group 11 had no inoculation but received 3.2 g. $\mathrm{L}^{-1}$ of CRF following the manufacturer's recommended application rate for plants in a 3.8-L container. Plants in group 12 were uninoculated and not fertilized to confirm whether uninoculated, unfertilized plants form nodules. Except for the plants in groups 9 and 10, plants were irrigated with $500 \mathrm{~mL}$ tap water $(\mathrm{pH}=7.8)$ every other day. A saucer was placed under a container before irrigation to collect leachate for measurements. $\mathrm{A}_{\mathrm{NO}_{3}}-\mathrm{N}$ meter (LAQUA Twin; Horiba, Kyoto, Japan) and a $\mathrm{pH}$ meter (LAQUA Twin) were used to record the $\mathrm{NO}_{3}-\mathrm{N}$ concentration and $\mathrm{pH}$ of the leachate weekly. The $\mathrm{NO}_{3}-\mathrm{N}$ concentration in the leachate of plants treated with CRF was calculated using the difference between $\mathrm{NO}_{3}-\mathrm{N}$ concentrations in irrigation water and in leachate to correct the variations from background $\mathrm{N}$.

Gas exchange parameters, including the leaf net photosynthesis rate $\left(\mathrm{P}_{\mathrm{n}}\right)$, stomatal conductance rate $\left(g_{\mathrm{S}}\right)$, and transpiration rate $(E)$, were recorded for plants treated with 0 , 2.0, 8.0, and $32.0 \mathrm{~g}$ of CRF 1 week before the experiment was ended. Parameters were recorded using a Portable Photosynthesis System with a PLC3 Universal Leaf Cuvette (CIRAS-3; PP Systems, Amesbury, MA) on a sunny day between 1000 and $1400 \mathrm{HR}$. Within the cuvette, the intensity of photosynthetic photon flux density was set at $1000 \mu \mathrm{mol} \cdot \mathrm{m}^{-2} \cdot \mathrm{s}^{-1}$ with $38 \%$ red, $37 \%$ green, and $25 \%$ blue light provided from light-emitting diodes, whereas the carbon dioxide level and leaf temperature were controlled at $400 \mu \mathrm{mol} \cdot \mathrm{mol}^{-1}$ and $25^{\circ} \mathrm{C}$, respectively.

The experiment was ended on 8 Dec. 2019. Plant height was recorded at the initiation and termination of the experiment to determine plant growth. Before all plants were destructively harvested, the number of shoots (longer than $5 \mathrm{~cm}$ ) was recorded for each plant. All $S$. Xutahensis 'Torrey' plants were destructively harvested, and the leaf area was recorded using a leaf area meter (LI3000; LI-COR Biosciences, Lincoln, NE). After roots were harvested and washed using deionized water, plants were checked for nodule number. Leaves, stems, and roots were dried in an oven at $80{ }^{\circ} \mathrm{C}$ for $3 \mathrm{~d}$, and the dry weight was recorded. Dry leaves and stem samples were ground and analyzed at the Utah State University Analytical Laboratories for $\mathrm{N}$ content with an elemental analyzer (vario MAX cube; Elementar Analysensysteme $\mathrm{GmbH}$, Langenselbold, Germany).

The experiment used a randomized complete block design with 10 blocks for all groups. An analysis of variance was performed to test the effects of treatments on plant morphological and physiological responses. The means separation among treatments was adjusted using the Tukey-Kramer method for multiplicity at $\alpha=0.05$. All statistical analyses were performed using the PROC Mixed procedure in SAS Studio (SAS Institute, Cary, NC).

\section{Results}

Leachate. The N-supplement and $\mathrm{N}$ lacking treatment led to leachate $\mathrm{NO}_{3}-\mathrm{N}$ concentrations of $188.3 \pm 13.5$ and $19.8 \pm$ $1.4 \mathrm{mg} \cdot \mathrm{L}^{-1}$ (mean $\pm \mathrm{SE}$ ), respectively. The $\mathrm{pH}$ values of the leachate solutions were $7.3 \pm 1.3$ and $7.6 \pm 1.3$ (mean $\pm \mathrm{SE}$ ) for $\mathrm{N}$-supplement and N-lacking treatment, respectively (data not shown). However, for plants irrigated with tap water, the $\mathrm{pH}$ of the leachate solution was $7.9 \pm 0.01($ mean $\pm \mathrm{SE})$. For plants treated with $\mathrm{CRF}$, the $\mathrm{NO}_{3}-\mathrm{N}$ concentration of leachate solution increased as the applied CRF levels increased (Fig. 1). The $\mathrm{NO}_{3}-\mathrm{N}$ concentrations of leachate solutions from plants treated with 0 to $2.1 \mathrm{~g} \cdot \mathrm{L}^{-1} \mathrm{CRF}$ were $28 \%$ to $80 \%$ less than that from uninoculated plants treated with the manufacturer's prescribed rate (Fig. 1). However, inoculated plants treated with 4.2 and $8.4 \mathrm{~g} \cdot \mathrm{L}^{-1} \mathrm{CRF}$ had $42 \%$ and $179 \%$ greater $\mathrm{NO}_{3}-\mathrm{N}$ leachate concentrations, respectively, than uninoculated plants treated with the manufacturer's prescribed rate.

Plant growth, number of shoots, and leaf area. Plant growth of $S$. ×utahensis 'Torrey' plants receiving the $\mathrm{N}$-supplement treatment was three times greater than that of plants receiving the $\mathrm{N}$-lacking treatment (Table 1). A regression analysis indicated a quadratic relationship between CRF and plant growth $\left(P=0.002 ; R^{2}=0.95\right)$ (Fig. 2). Plant growth and visual quality are shown in Fig. 3. Plant growth of inoculated $S$. ×utahensis 'Torrey' plants treated with 1.1 to $8.4 \mathrm{~g} \cdot \mathrm{L}^{-1} \mathrm{CRF}$ increased one to six times compared with plants treated with $0 \mathrm{~g} \cdot \mathrm{L}^{-1} \mathrm{CRF}$. A quadratic trend in CRF and the number of shoots of $S$. Xutahensis 'Torrey' $\left(P=0.003 ; R^{2}=0.95\right)$ was observed (Fig. 2). Except for the plants receiving $0.3 \mathrm{~g} \cdot \mathrm{L}^{-1} \mathrm{CRF}, \mathrm{S}$. $\times$ utahensis 'Torrey' plants treated with 0.1 to $8.4 \mathrm{~g} \cdot \mathrm{L}^{-1} \mathrm{CRF}$ had one to four more shoots than plants treated with $0 \mathrm{~g} \cdot \mathrm{L}^{-1} \mathrm{CRF}$. The leaf area of $S$. Xutahensis 'Torrey' plants receiving $\mathrm{N}$ supplement treatment was four times more than that of N-lacking treatment (Table 1). When plants were fertilized with increasing amounts of CRF, a quadratic relationship was found between the leaf area and CRF $(P=$ $0.007 ; R^{2}=0.98$ ) (Fig. 2). When $S$. $\times$ utahensis 'Torrey' plants were treated with 1.1 to $8.4 \mathrm{~g} \cdot \mathrm{L}^{-1} \mathrm{CRF}$, the leaf area was one to three times greater than those treated with 


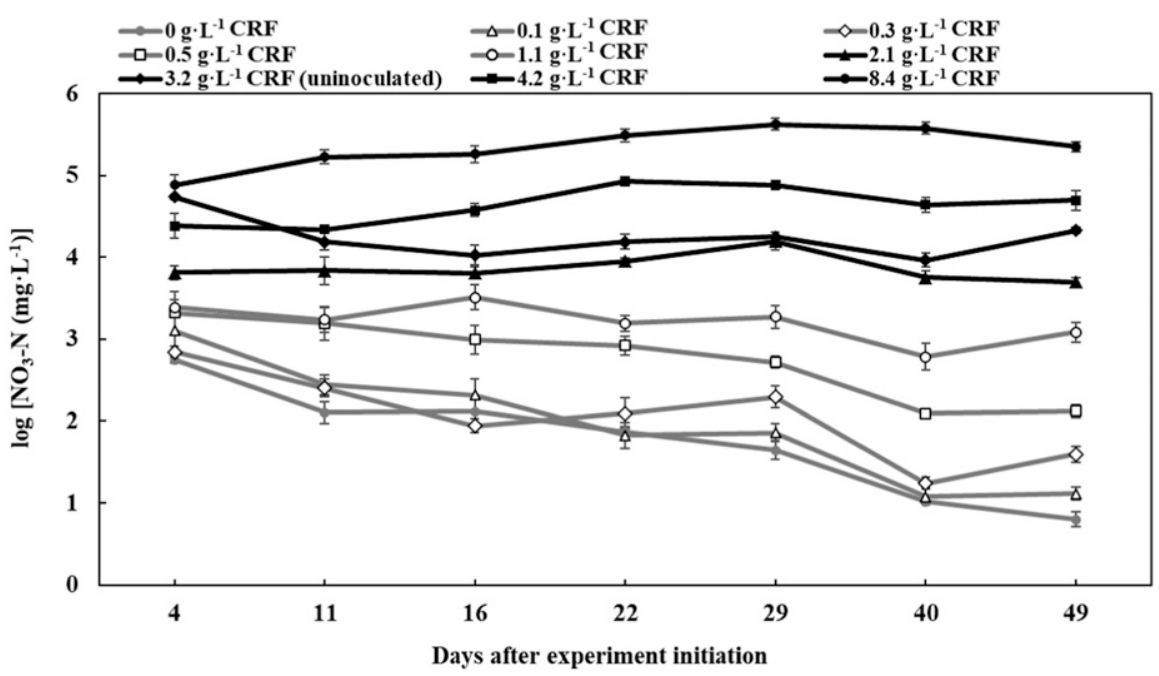

Fig. 1. Nitrate-nitrogen $\left(\mathrm{NO}_{3}-\mathrm{N}\right)$ concentrations of leachate recorded after Shepherida $\times$ utahensis 'Torrey' plants topdressed with 0 to $8.4 \mathrm{~g} \cdot \mathrm{L}^{-1}$ controlled-release fertilizer (CRF; $15 \mathrm{~N}-3.9 \mathrm{P}-10 \mathrm{~K}$ ) were irrigated with tap water. The error bars represent the SE of five samples. The background nitrogen in tap water was corrected by calculating the difference between $\mathrm{NO}_{3}-\mathrm{N}$ concentrations in leachate and tap water.

Table 1. Plant growth, number of shoots, leaf area, dry weights (DW) of leaf, stem, and root, and number of nodules of inoculated Shepherdia $\times$ utahensis 'Torrey' treated with nutrient solution supplemented with (N-supplement) or not supplemented with (N-lacking) $2 \mathrm{~mm}$ ammonium nitrate $\left(\mathrm{NH}_{4} \mathrm{NO}_{3}\right)$ for 8 weeks.

\begin{tabular}{lccccccc}
\hline Treatment & $\begin{array}{c}\text { Plant growth } \\
(\mathrm{cm})\end{array}$ & $\begin{array}{c}\text { Shoots } \\
(\text { no. })\end{array}$ & $\begin{array}{c}\text { Leaf area } \\
\left(\mathrm{cm}^{2}\right)\end{array}$ & $\begin{array}{c}\text { Leaf } \\
\text { DW }(\mathrm{g})\end{array}$ & $\begin{array}{c}\text { Stem } \\
\text { DW }(\mathrm{g})\end{array}$ & $\begin{array}{c}\text { Root } \\
\text { DW }(\mathrm{g})\end{array}$ & $\begin{array}{c}\text { Nodules } \\
(\text { no. })\end{array}$ \\
\hline N-supplement & 8.4 & 2.7 & 154.2 & 1.6 & 0.6 & 1.0 & 0.1 \\
N-lacking & 2.2 & 0.1 & 34.6 & 0.5 & 0.2 & 0.2 & 10.8 \\
$P$ value & $* * * *$ & $* * *$ & $* * *$ & $* * * *$ & $* *$ & $* * * *$ & $* * * *$ \\
\hline
\end{tabular}

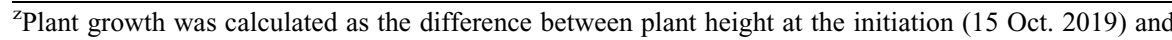
termination (8 Dec. 2019) of the experiment.

$* *, * * *, * * * *$ Significant at $P \leq 0.01,0.001$, or 0.0001 , respectively.

$0 \mathrm{~g} \cdot \mathrm{L}^{-1} \mathrm{CRF}$. No significant difference was found for these parameters of uninoculated $S$. $\times$ utahensis 'Torrey' plants treated with the manufacturer's prescribed rate and inoculated plants treated with 1.1 and $2.1 \mathrm{~g} \cdot \mathrm{L}^{-1}$ CRF.

Dry weight of leaf, stem, and root. Leaf dry weight of $S$. ×utahensis 'Torrey' plants receiving $\mathrm{N}$-supplement treatment was two times greater than plants with the N-lacking treatment (Table 1). A quadratic relationship was found between leaf dry weight and CRF amounts in inoculated plants $(P=0.0002$; $R^{2}=0.97$ ) (Fig. 2). Leaf dry weight of $S$. $\times$ utahensis 'Torrey' plants treated with 2.1, 4.2, and $8.4 \mathrm{~g} \cdot \mathrm{L}^{-1} \mathrm{CRF}$ was three, four, and five times greater, respectively, than those treated with $0 \mathrm{~g} \cdot \mathrm{L}^{-1} \mathrm{CRF}$. The $\mathrm{N}$-supplement treatment increased the stem dry weight of $S$. $\times$ utahensis 'Torrey' plants by $130 \%$ compared with plants given the N-lacking treatment (Table 1). When inoculated $S$. ×utahensis 'Torrey' plants were treated with increasing amounts of CRF, a quadratic relationship was found between CRF and stem dry weight $\left(P=0.03 ; R^{2}=0.98\right)$ (Fig. 2). Compared with plants treated with 0 g. $\mathrm{L}^{-1} \mathrm{CRF}$, the stem dry weight of $S$. $\times$ utahensis 'Torrey' treated with 4.2 and $8.4 \mathrm{~g} \cdot \mathrm{L}^{-1} \mathrm{CRF}$ increased two and three times, respectively. Shepherdia $\times$ utahensis 'Torrey' had four times greater root dry weight when $\mathrm{N}$-supplement treatment was applied compared with $\mathrm{N}$ lacking treatment (Table 1). A quadratic relationship was observed between CRF and root dry weight of $S$. $\times$ utahensis 'Torrey' $(P=0.01$; $R^{2}=0.91$ ) (Fig. 2), and the root dry weight increased approximately five times for plants treated with 4.2 and $8.4 \mathrm{~g} \cdot \mathrm{L}^{-1} \mathrm{CRF}$ compared with plants treated with $0 \mathrm{~g} \cdot \mathrm{L}^{-1} \mathrm{CRF}$ (Fig. 3). These parameters of uninoculated $S$. $\times$ utahensis 'Torrey' treated with the manufacturer's prescribed rate were not different from those of inoculated $S$. Xutahensis 'Torrey' plants treated with 1.1 and $2.1 \mathrm{~g} \cdot \mathrm{L}^{-1} \mathrm{CRF}$ (Fig. 2). However, no significant difference in the root:shoot ratio was observed between inoculated and uninoculated plants receiving no $\mathrm{CRF}(P=0.3)$ (data not shown). In addition, no correlation was observed between the root:shoot ratio and nodule and growth parameters in this study (data not shown).

Gas exchange and shoot $N$ content. A positive linear relationship was exhibited between CRF and the $\mathrm{P}_{\mathrm{n}}$ of $S$. Xutahensis 'Torrey' $\left(P<0.0001 ; r^{2}=0.74\right)$ (Fig. 4). The $\mathrm{P}_{\mathrm{n}}$ of $S$. $\times$ utahensis 'Torrey' plants treated with 2.1 and $8.4 \mathrm{~g} \cdot \mathrm{L}^{-1} \mathrm{CRF}$ increased 12 and 16 times, respectively, compared with plants treated with $0 \mathrm{~g} \cdot \mathrm{L}^{-1} \mathrm{CRF}$. The $g_{\mathrm{S}}$ of $S$. $\times$ utahensis 'Torrey' increased linearly with increasing CRF $\left(P=0.004 ; r^{2}=0.66\right)$ (Fig. 4), and the $g_{\mathrm{S}}$ of plants treated with
8.4 g. $\mathrm{L}^{-1} \mathrm{CRF}$ was $72 \%$ greater than that of plants treated with $0 \mathrm{~g} \cdot \mathrm{L}^{-1} \mathrm{CRF}$. The $E$ of $S$. Xutahensis 'Torrey' had a positive linear trend with increasing CRF $\left(P=0.005 ; r^{2}=\right.$ $0.69)$. Shepherdia $\times$ utahensis 'Torrey' plants treated with $8.4 \mathrm{~g} \cdot \mathrm{L}^{-1} \mathrm{CRF}$ had a $54 \%$ increase in $E$ compared with plants treated with 0 g. $\mathrm{L}^{-1} \mathrm{CRF}$. No statistical difference was found in the $\mathrm{P}_{\mathrm{n}}, g_{\mathrm{S}}$, and $E$ of $S$. Xutahensis 'Torrey' plants receiving 2.1 and $8.4 \mathrm{~g} \cdot \mathrm{L}^{-1}$ CRF.

The shoot $\mathrm{N}$ content of inoculated $S$. Xutahensis 'Torrey' plants increased linearly with CRF $\left(P<0.0001 ; r^{2}=0.84\right)$. When $S$. Xutahensis 'Torrey' was fertilized with 2.1 and $8.4 \mathrm{~g} \cdot \mathrm{L}^{-1} \mathrm{CRF}$, the shoot $\mathrm{N}$ content increased by $44 \%$ and $71 \%$, respectively, compared with plants treated with $0 \mathrm{~g} \cdot \mathrm{L}^{-1}$ CRF. There was no statistical difference in the shoot N content of inoculated $S$. $\times$ utahensis 'Torrey' treated with 2.1 or 8.4 $\mathrm{g} \cdot \mathrm{L}^{-1} \mathrm{CRF}$ and uninoculated plants that received the manufacturer's prescribed rate (Fig. 4).

Nodulation. Nodules formed on $S$. $\times$ utahensis 'Torrey' plants inoculated with Frankia-infected soils in our experiment $(P<$ $0.0001)$, whereas plants without inoculation and treated with $0 \mathrm{~g} \cdot \mathrm{L}^{-1} \mathrm{CRF}$ did not form any nodules (data not shown). Furthermore, uninoculated plants treated with the manufacturer's recommended rate did not form nodules. The $\mathrm{NH}_{4} \mathrm{NO}_{3}$ in the nutrient solution and CRF affected the nodule number of $S$. ×utahensis 'Torrey' (both $P<0.0001$ ) (data not shown). When the $\mathrm{N}$-supplement treatment was applied, one nodule appeared on 1 out of 10 inoculated $S$. ×utahensis 'Torrey' plants (Table 1). In contrast, for plants receiving $\mathrm{N}$-lacking treatment, all plants formed nodules, with 10 nodules per plant on average. For the inoculated plants treated with CRF, the number of nodules per plant decreased quadratically as CRF increased $\left(P<0.0001 ; R^{2}=0.74\right)$ (Figs. 3 and $5)$. When inoculated with soils containing infective Frankia strains, S. ×utahensis 'Torrey' topdressed with 8.4 g. $\mathrm{L}^{-1} \mathrm{CRF}$ did not form any nodules, whereas 1 out of 10 plants treated with $4.2 \mathrm{~g} \cdot \mathrm{L}^{-1} \mathrm{CRF}$ had one nodule. According to the regression analysis, $2.9 \mathrm{~g} \cdot \mathrm{L}^{-1}$ CRF completely inhibited nodule formation. The dry weight of nodules increased quadratically as CRF increased $\left(P=0.006 ; R^{2}=0.94\right)$. The dry weight of nodules on plants treated with $2.1 \mathrm{~g} \cdot \mathrm{L}^{-1} \mathrm{CRF}$ was 13 times greater than that of plants treated with $0 \mathrm{~g} \cdot \mathrm{L}^{-1} \mathrm{CRF}$ (Fig. 5).

\section{Discussion}

Leachate. Factors such as environmental temperature and physical properties of CRF coating affect the release rate of CRF; however, generally, Osmocote has a relatively rapid release rate initially, followed by a steadily decreasing rate of release over time (Adams et al., 2013). A similar pattern was found in our study; leachate $\mathrm{NO}_{3}-\mathrm{N}$ concentrations increased at an early stage of the experiment and then decreased over time in 
$\bullet$ Inoculated plants
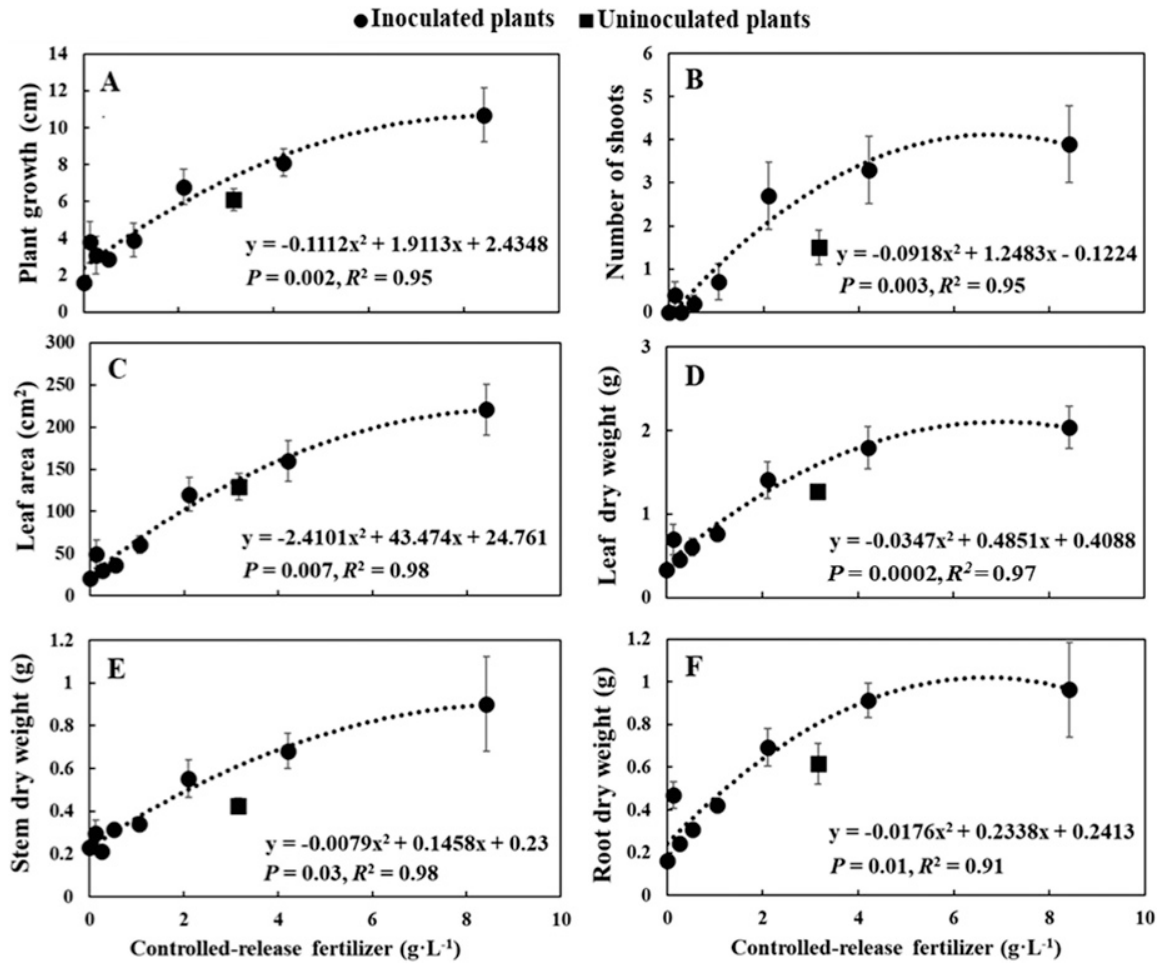

Fig. 2. Plant growth (A), number of shoots $(\mathbf{B})$, leaf area (C), leaf dry weight $(\mathbf{D})$, stem dry weight $(\mathbf{E})$, and root dry weight $(\mathbf{F})$ of Shepherdia $\times$ utahensis 'Torrey' inoculated with soil containing infective Frankia and topdressed with 0 to $8.4 \mathrm{~g} \cdot \mathrm{L}^{-1}$ controlled-release fertilizer (CRF; $15 \mathrm{~N}-3.9 \mathrm{P}-10 \mathrm{~K}$ ) for 8 weeks. The round markers represent means of the plants inoculated with Frankia, whereas the square markers represent the uninoculated plants treated with the manufacturer's prescribed rate of $3.2 \mathrm{~g} \cdot \mathrm{L}^{-1}$ A regression analysis was conducted using the plants inoculated with Frankia. The error bars represent the SE of 10 samples. No significant difference was found between the inoculated plants treated with 1.1 and $2.1 \mathrm{~g} \cdot \mathrm{L}^{-1} \mathrm{CRF}$ and uninoculated plants treated with the manufacturer's prescribed rate according to the Tukey-Kramer method for multiplicity at $\alpha=0.05$. plants receiving 2.1 to 8.4 g. $\mathrm{L}^{-1} \mathrm{CRF}$ (Fig. 1). The trend of increasing $\mathrm{NO}_{3}-\mathrm{N}$ concentrations in the leachate at the early stage of the experiment followed by declining concentrations was also reported by Glenn et al. (2000) and Niemiera and Leda (1993). This pattern was also reported for $A$. maritima plants grown in a substrate containing peat and vermiculite and treated with $\mathrm{CRF}$; the $\mathrm{NO}_{3}$ $\mathrm{N}$ concentration in the leachate increased from days 1 to 14 for plants receiving 3.6 and $7.3 \mathrm{~g} \cdot \mathrm{L}^{-1}$ Osmocote $15 \mathrm{~N}-3.9 \mathrm{P}-10 \mathrm{~K}$ and then decreased (Beddes and Kratsch, 2010). The increasing $\mathrm{NO}_{3}-\mathrm{N}$ concentration in growing substrates during the early period of the experiment could delay nodule formation.

Morphological and physiological responses. In our study, although morphological parameters of $S$. xutahensis 'Torrey' increased quadratically with increasing CRF levels, these parameters did not change significantly when fertilizer levels exceeded $2.1 \mathrm{~g} \cdot \mathrm{L}^{-1} \mathrm{CRF}(\approx 0.3$ g. $\mathrm{L}^{-1} \mathrm{~N}$ ) (Fig. 2). This may be because plant growth responses do not correlate well with nutrient availability when the substrate nutrient concentration exceeds a certain range (Taiz et al., 2015). For example, for morphological parameters, the shoot dry weight of Salvia farinacea (mealycup sage) increased quadratically with Osmocote $39 \mathrm{~N}-0 \mathrm{P}-0 \mathrm{~K}$, increasing from 0.5 to $3.0 \mathrm{~g} \cdot \mathrm{L}^{-1} \mathrm{~N}$, but increasing the rate of Osmocote $39 \mathrm{~N}-0 \mathrm{P}-0 \mathrm{~K}$ did not contribute to the shoot dry weight when it exceeded $2.0 \mathrm{~g} \cdot \mathrm{L}^{-1} \mathrm{~N}$ (Knowles et al., 1993). Beddes and Kratsch (2010) also reported that leaf area, shoot dry weight, and root dry weight of $A$. maritima did

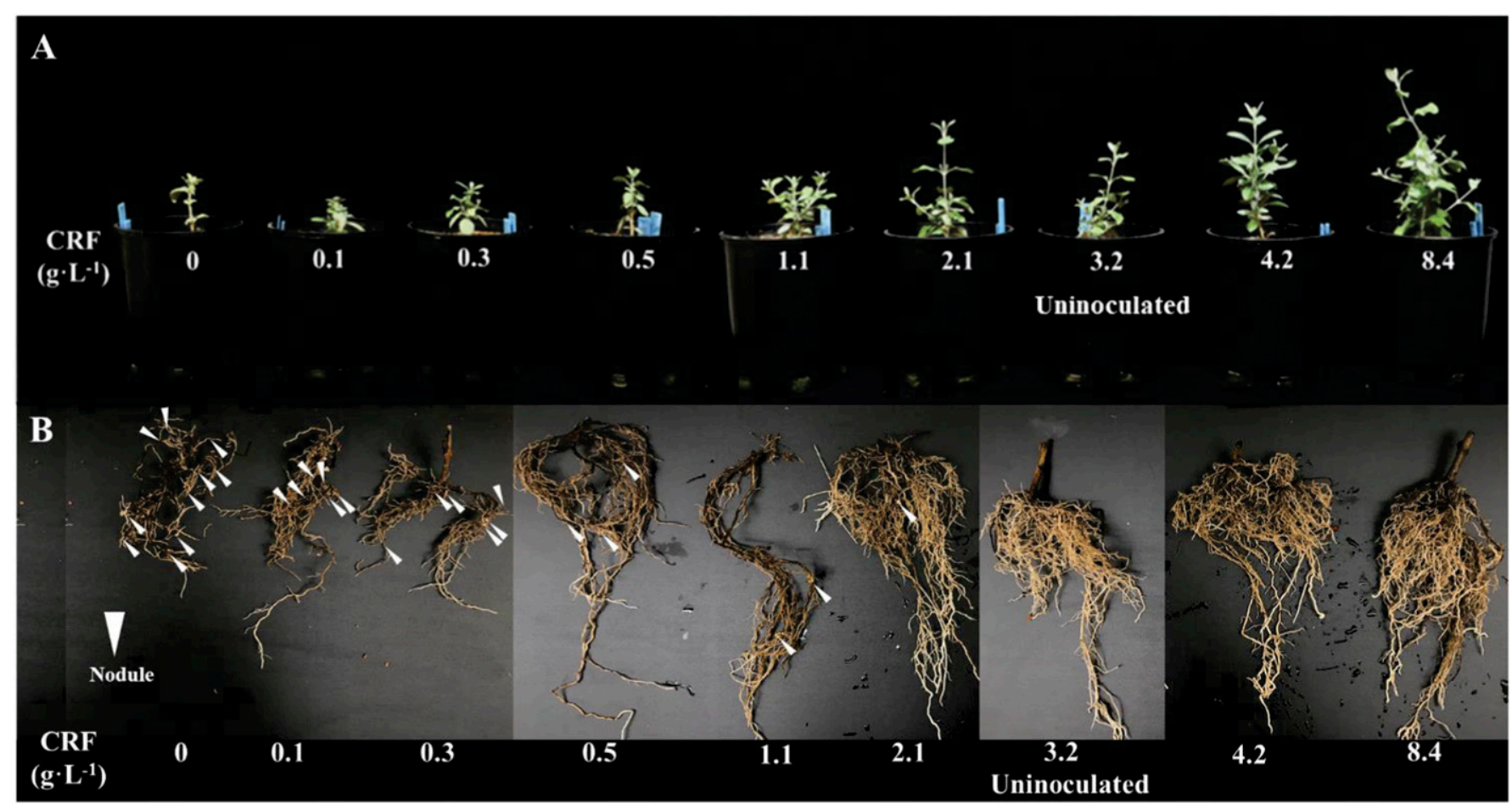

Fig. 3. The shoot (A) and root (B) of Shepherdia $\times$ utahensis 'Torrey' plants inoculated with soil containing infective Frankia and topdressed with 0 to 8.4 g. L $^{-1}$ controlled-release fertilizer (CRF; $15 \mathrm{~N}-3.9 \mathrm{P}-10 \mathrm{~K}$ ) and the uninoculated plants that received the manufacturer's prescribed rate of $3.2 \mathrm{~g} \cdot \mathrm{L}^{-1}$. Inoculated $S$ xutahensis 'Torrey' plants that received 1.1 and $2.1 \mathrm{~g} \cdot \mathrm{L}^{-1} \mathrm{CRF}$ had plant vigor similar to that of uninoculated plants that received the manufacturer's prescribed application. Photos were obtained at week 8 of the experiment. 
-Inoculated plants
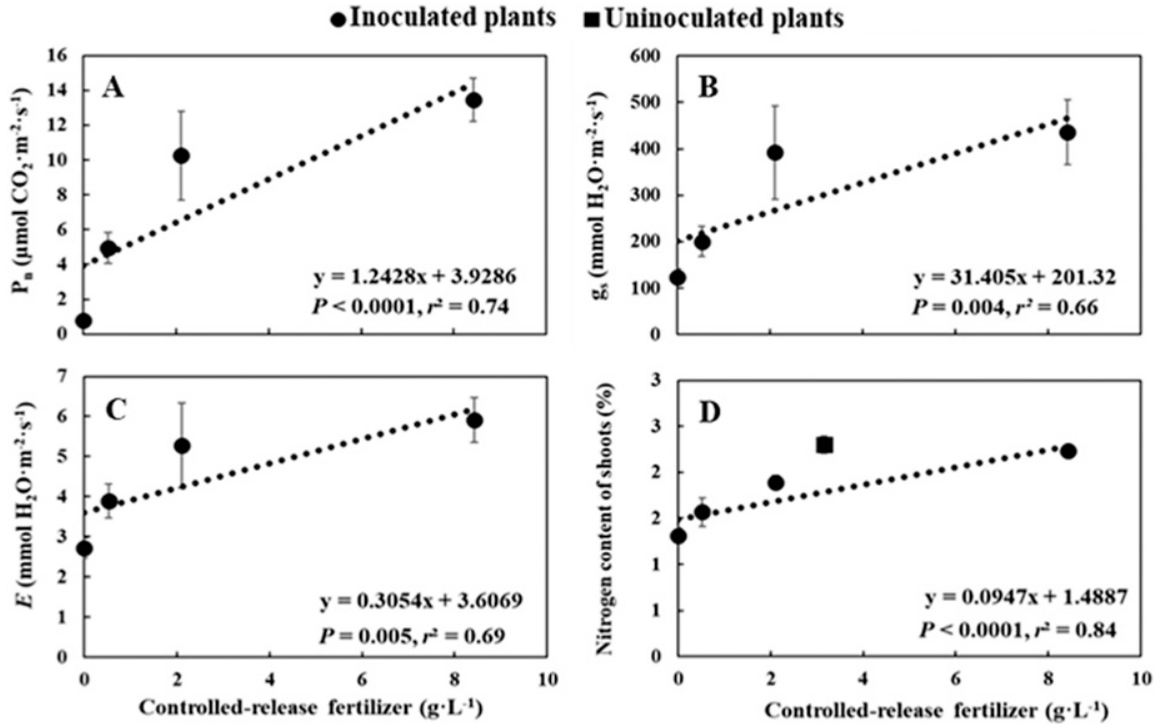

Fig. 4. The photosynthesis rate $\left(\mathrm{P}_{\mathrm{n}}\right)(\mathbf{A})$, stomatal conductance rate $\left(g_{\mathrm{S}}\right)(\mathbf{B})$, transpiration rate $(E)(\mathbf{C})$, and nitrogen content of shoot $(\mathbf{D})$ of Shepherdia $\times$ utahensis 'Torrey' topdressed with $0 \mathrm{~g} \cdot \mathrm{L}^{-1}, 0.5 \mathrm{~g} \cdot \mathrm{L}^{-1}, 2.1$ $\mathrm{g} \cdot \mathrm{L}^{-1}$, and $8.4 \mathrm{~g} \cdot \mathrm{L}^{-1}$ of controlled-release fertilizer $(\mathrm{CRF} ; 15 \mathrm{~N}-3.9 \mathrm{P}-10 \mathrm{~K})$ for 8 weeks. The error bars represent the SE of four measurements or samples. The round markers represent means of the plants inoculated with Frankia, whereas the square marker in the shoot nitrogen content represents the uninoculated plants that received the manufacturer's prescribed rate of $3.2 \mathrm{~g} \cdot \mathrm{L}^{-1} \mathrm{CRF}$. A regression analysis was conducted using the plants inoculated with Frankia. No significant differences were found in the nitrogen contents of shoots of the inoculated plants treated with $2.1 \mathrm{~g} \cdot \mathrm{L}^{-1} \mathrm{CRF}$ and uninoculated plants treated with the manufacturer's prescribed rate according to Tukey-Kramer method for multiplicity at $\alpha=0.05$.
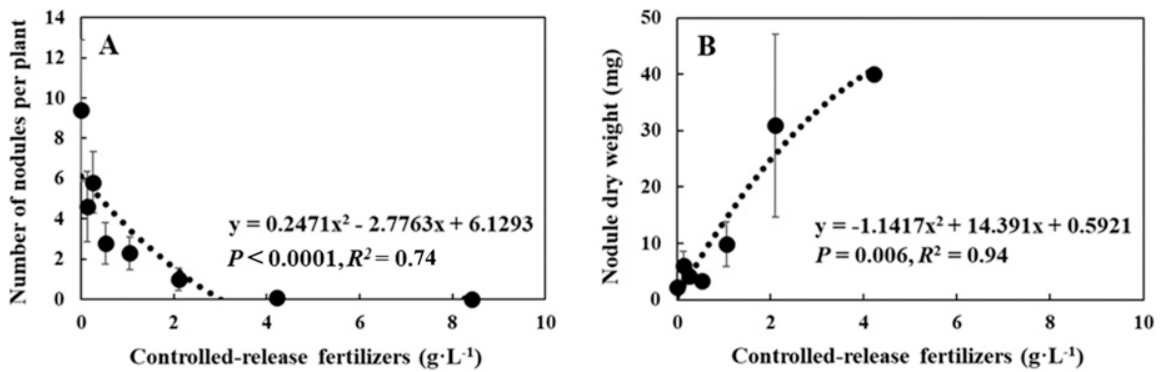

Fig. 5. The number of nodules per plant (A) and nodule dry weight (B) of Shepherdia $\times$ utahensis 'Torrey' inoculated with soil containing infective Frankia and topdressed with 0 to $8.4 \mathrm{~g} \cdot \mathrm{L}^{-1}$ controlled-release fertilizer (CRF; 15N-3.9P-10K) for 8 weeks. A regression analysis was conducted using the plants inoculated with Frankia. The error bars represent the SE of 10 samples.

not increase when Osmocote $15 \mathrm{~N}-3.9 \mathrm{P}-10 \mathrm{~K}$ was more than $3.6 \mathrm{~g} \cdot \mathrm{L}^{-1}\left(\approx 0.5 \mathrm{~g} \cdot \mathrm{L}^{-1} \mathrm{~N}\right)$.

Physiological parameters of $S$. ×utahensis 'Torrey' increased linearly with increasing CRF levels (Fig. 4), which is inconsistent with a previous report indicating that a quadratic relationship generally occurs between plant growth and nutrient availability (Taiz et al., 2015). Actually, our data points strongly resemble quadratic trends (Fig. 4) because the physiological parameters did not change significantly when CRF levels exceeded $2.1 \mathrm{~g} \cdot \mathrm{L}^{-1} \mathrm{CRF}\left(\approx 0.3 \mathrm{~g} \cdot \mathrm{L}^{-1} \mathrm{~N}\right)$. This discrepancy might have resulted from numerous variations in the physiological data that were recorded and the limited number of treatments. The $\mathrm{P}_{\mathrm{n}}$ of Abies fraseri (fraser fir), Picea glauca (white spruce), Picea pungens (blue spruce), and Pinus strobus (eastern white pine) increased when Osmocote $15 \mathrm{~N}-$ levels. Klooster et al. (2010) reported that the $\mathrm{N}$ contents of $A$. fraseri, $P$. glauca, $P$. pungens, and $P$. strobus needles increased when the Osmocote $15 \mathrm{~N}-3.9 \mathrm{P}-10 \mathrm{~K}$ application increased from 0.25 and $0.5 \mathrm{~g} \cdot \mathrm{L}^{-1} \mathrm{~N}$. The N contents of Pilea 'Silver Tree', Aphelandra squarrosa (zebra plant), Chamaedorea elegans (parlor palm), and Dieffenbachia maculata 'Camille' ('Camille' dumb cane) increased linearly with the $14 \mathrm{~N}-6.2 \mathrm{P}-11.6 \mathrm{~K}$ slow-release fertilizer level increasing from 0.5 to $1.5 \mathrm{~g} \cdot \mathrm{L}^{-1}\left(\approx 0.07\right.$ to $\left.0.2 \mathrm{~g} \cdot \mathrm{L}^{-1} \mathrm{~N}\right)$ (Poole and Conover, 1989). In the study by Knowles et al. (1993), the shoot N content of Salvia farinacea showed a quadratic trend with increasing Osmocote $39 \mathrm{~N}-0 \mathrm{P}-0 \mathrm{~K}$. The $\mathrm{N}$ content of A. maritima increased quadratically with increasing application rates of Osmocote $15 \mathrm{~N}-3.9 \mathrm{P}-10 \mathrm{~K}$, but the shoot $\mathrm{N}$ contents of nodulated $A$. maritima plants receiving 0.9 to $1.8 \mathrm{~g} \cdot \mathrm{L}^{-1} \mathrm{CRF}(\approx 0.1$ to 0.3 $\mathrm{g} \cdot \mathrm{L}^{-1} \mathrm{~N}$ ) were not different from those of uninoculated plants receiving the manufacturer's prescribed rate of $2.7 \mathrm{~g} \cdot \mathrm{L}^{-1} \mathrm{CRF}(\approx 0.4$ $\left.\mathrm{g} \cdot \mathrm{L}^{-1} \mathrm{~N}\right)$ because of the $\mathrm{N}_{2}$-fixing ability of Frankia (Beddes and Kratsch, 2010). The leaf $\mathrm{N}$ content of $A$. maritima plants also increased along with $\mathrm{NH}_{4} \mathrm{NO}_{3}$ levels in the nutrient solution (Laws and Graves, 2005). In our study, the shoot $\mathrm{N}$ content of nodulated $S$. $\times$ utahensis 'Torrey' plants fertilized with 2.1 $\mathrm{g} \cdot \mathrm{L}^{-1} \mathrm{CRF}$ was similar to that of uninoculated plants receiving the manufacturer's prescribed rate of $3.2 \mathrm{~g} \cdot \mathrm{L}^{-1}$. These results indicate that nodulation induced by Frankia may help accumulate $\mathrm{N}$. Because the $\mathrm{N}_{2}$-fixation of Frankia enhances the $\mathrm{N}$ content, inducing nodules in novel actinorhizal plants using field soil is a preferred practice to reduce fertilizer applications in sustainable nurseries concerned with the economic and ecological impacts of chemical fertilizers (Kratsch and Graves, 2004).

Soils from actinorhizal plant habitats have dense populations of infective Frankia, and host plants are the primary factor amplifying Frankia populations in the soil (Benson and Silvester, 1993; Schwencke and Caru, 2001). In our study, soil used for inoculation was collected from the rhizosphere of a $S$. Xutahensis 'Torrey' in North Logan, UT. Our results suggest that this soil has infective Frankia to induce symbiotic nodules of $S$. Xutahensis 'Torrey', which is similar to previous reports indicating that soils collected from wild populations have significant effects on inducing nodules on actinorhizal plants (Beddes and Kratsch, 2010; Jeong and Myrold, 2001; Laws and Graves, 2005).

Although soil can induce nodules on $S$. $\times$ utahensis 'Torrey', such nodule formation was inhibited by $2.9 \mathrm{~g} \cdot \mathrm{L}^{-1} \mathrm{CRF}\left(\approx 0.4 \mathrm{~g} \cdot \mathrm{L}^{-1}\right.$ $\mathrm{N})$ or $2 \mathrm{~mm} \mathrm{NH}_{4} \mathrm{NO}_{3}$. This might be associated with the significant impact of $\mathrm{N}$ fertilizer on the infection process of actinorhizal plants. Depending on the host plant species, Frankia strains infect host plants by either root hair infection or intercellular penetration (Schwencke and Caru, 2001). Nitrate has a negative effect on root hair development; 
therefore, the nodule number is more sensitive to nitrate in actinorhizal plants with root hair infection. For instance, Alnus glutinosa (black alder), Casuarina cunninghamiana (river oak), and Myrica cerifera (southern wax myrtle) are infected by Frankia via root hair infection, and their nodule formation is more sensitive to nitrate when compared with Elaeagnus angustifolia (Russian olive), which is infected by Frankia via intercellular penetration (Kohls and Baker, 1989). Ammonium ions in substrate may impact nodule formation, but the substrate used for growing $S$. ×utahensis 'Torrey' is well-drained, a condition under which $\mathrm{N}$ fertilizer tends to transform to nitrate (Norton and Ouyang, 2019). This nitrate, together with those released from fertilizer, would significantly inhibit the Frankia infection process of $S . \times$ utahensis 'Torrey'. However, further investigations should be conducted to confirm the mechanism of Frankia strains infecting $S$. Xutahensis 'Torrey' because they infect most Shepherdia species via intercellular penetration (Racette and Torrey, 1989) and, therefore, would not be sensitive to nitrate.

Additionally, the reliance of host plants on the symbiont decreases when the plant $\mathrm{N}$ status increases; therefore, autoregulation is triggered to suppress nodule formation and prevent excessive export of photosynthate (Kratsch and Graves, 2004). The sensitivity of nodule formation to $\mathrm{N}$ is different among actinorhizal plants. Thomas and Berry (1989) reported that the nodule number on Ceanothus griseus (carmel ceanothus) was significantly reduced at $0.714 \mathrm{~mm} \mathrm{NH}_{4} \mathrm{NO}_{3}$ and completely inhibited at $2.68 \mathrm{~mm} \mathrm{NH} \mathrm{NH}_{4} \mathrm{NO}_{3}$. However, Purshia mexicana (Mexican cliffrose) and Purshia tridentata (antelope bitterbrush) did not form nodules when exposed to $6 \mathrm{~mm} \mathrm{NH}_{4} \mathrm{NO}_{3}$ (Righetti et al., 1986). For A. maritima, the nodule number decreased linearly when the $\mathrm{NH}_{4} \mathrm{NO}_{3}$ concentration increased from 0.25 to $4 \mathrm{~mm}$, and it was completely inhibited at $8 \mathrm{~mm} \mathrm{NH}_{4} \mathrm{NO}_{3}$ (Laws and Graves, 2005). In another study, the nodule number of $A$. maritima declined when Osmocote $15 \mathrm{~N}-3.9 \mathrm{P}-10 \mathrm{~K}$ exceeded 1.8 $\mathrm{g} \cdot \mathrm{L}^{-1}\left(\approx 0.3 \mathrm{~g} \cdot \mathrm{L}^{-1} \mathrm{~N}\right)$, and it was completely inhibited at $3.6 \mathrm{~g} \cdot \mathrm{L}^{-1} \mathrm{CRF}\left(\approx 0.5 \mathrm{~g} \cdot \mathrm{L}^{-1} \mathrm{~N}\right)$ (Beddes and Kratsch, 2010). Compared with A. maritima, the nodule formation of $S$. xutahensis 'Torrey' is completely inhibited by a relatively lower concentration of $\mathrm{NH}_{4} \mathrm{NO}_{3}$ or CRF level. Therefore, $S$. xutahensis 'Torrey' may be sensitive to environmental $\mathrm{N}$ content.

Apart from $\mathrm{N}$, mineral nutrients in the $\mathrm{CRF}$ and substrate $\mathrm{pH}$ might also affect the nodule number of $S$. Xutahensis 'Torrey'. Although $\mathrm{NO}_{3}-\mathrm{N}$ and ammonium-nitrogen $\left(\mathrm{NH}_{4} \mathrm{NO}_{3}-\mathrm{N}\right)$ are the primary nutrients in Osmocote $15 \mathrm{~N}-3.9 \mathrm{P}-10 \mathrm{~K}$, it also contains mineral nutrients such as phosphate and iron (Adams et al., 2013). A previous study has documented that phosphate, cobalt, iron, calcium, and sodium affect the nodule number of actinorhizal plants (Huss-Danell, 1997). For instance, low phosphorus availability significantly impaired the nodule formation of Discaria trinervis (Valverde et al., 2002). Although substrate $\mathrm{pH}$ was not controlled in this experiment, it might affect the availability of macronutrients and micronutrients to inhibit nodulation (Huss-Danell, 1997; Taiz et al., 2015).

However, the $\mathrm{N}$ fixing ability of actinorhizal plants is related to nodule biomass instead of nodule number (Dawson and Gordon, 1979; Gordon and Wheeler, 1987). For S. Xutahensis 'Torrey', nodule dry weight increased with increasing CRF levels (Fig. 5), and a similar result was reported by Beddes and Kratsch (2010). These results indicate that the $\mathrm{N}$ fixation ability of $S$. $\times$ utahensis 'Torrey' may increase with increasing CRF levels up to $2.1 \mathrm{~g} \cdot \mathrm{L}^{-1}$. Although the $\mathrm{N}_{2}$ fixation capacity of nodules of $S$. $\times$ utahensis 'Torrey' was undefined in our study, our results indicate that Frankia inoculation could improve plant performance and reduce fertilizer use. Further investigations are needed to test the $\mathrm{N}_{2}$ fixation of $S$. Xutahensis 'Torrey' using acetylene reduction assays or ${ }^{15} \mathrm{~N}$ labeling techniques (Huss-Danell, 1997; Laws and Graves, 2005).

For acceptable plant quality and minimal $\mathrm{NO}_{3}-\mathrm{N}$ concentrations in leachate, Beddes and Kratsch (2010) concluded that $0.9 \mathrm{~g} \cdot \mathrm{L}^{-1}$ Osmocote $15 \mathrm{~N}-3.9 \mathrm{P}-10 \mathrm{~K}$ was the proper application rate for producing nodulated $A$. maritima. In addition, $\mathrm{NH}_{4} \mathrm{NO}_{3}$ at 0.5 to $2.0 \mathrm{~mm}$ in nutrient solution was recommended by Laws and Graves (2005) for $A$. maritima with symbiotic nodules to enhance leaf $\mathrm{N}$ as well as maintain plant vigor. In our research, plant growth was similar between the inoculated plants fertilized with $1.1 \mathrm{~g}$ and $2.1 \mathrm{~g} \cdot \mathrm{L}^{-1} \mathrm{CRF}$ and the uninoculated plants receiving the manufacturer's prescribed rate. Furthermore, inoculated plants treated with $2.1 \mathrm{~g} \cdot \mathrm{L}^{-1} \mathrm{CRF}$ had tissue $\mathrm{N}$ content similar to that of the uninoculated plants receiving the manufacturer's prescribed rate. Therefore, 1.1 or $2.1 \mathrm{~g} \cdot \mathrm{L}^{-1} \mathrm{CRF}$ may be the proper application rate for the production of nodulated $S$. ×utahensis 'Torrey'.

\section{Conclusions}

Although growth and physiological responses of $S$. xutahensis 'Torrey' were improved by increasing CRF, increased CRF led to higher $\mathrm{NO}_{3}-\mathrm{N}$ concentrations in the leachate. No significant differences in morphological and physiological parameters and shoot $\mathrm{N}$ contents were observed in the inoculated plants when CRF levels exceeded 2.1 $\mathrm{g} \cdot \mathrm{L}^{-1}$. Furthermore, compared with the uninoculated plants treated with the manufacturer's prescribed rate, nodulated plants treated with $1.1 \mathrm{~g} \cdot \mathrm{L}^{-1} \mathrm{CRF}$ had similar morphological and growth responses, and nodulated plants at $2.1 \mathrm{~g} \cdot \mathrm{L}^{-1}$ had similar shoot $\mathrm{N}$ contents. The number of nodules on $S$. $\times$ utahensis 'Torrey' was inhibited with increased CRF application rates, and it was completely inhibited by $2.9 \mathrm{~g} \cdot \mathrm{L}^{-1}$ of CRF or $2 \mathrm{~mm} \mathrm{NH}_{4} \mathrm{NO}_{3}$. Therefore, when nodulated $S$. $\times$ utahensis 'Torrey' plants are produced in the nursey, CRF lower than $2.9 \mathrm{~g} \cdot \mathrm{L}^{-1}$ or
$\mathrm{NH}_{4} \mathrm{NO}_{3}$ lower than $2 \mathrm{~mm}$ should be applied. Rates between 1.1 and $2.1 \mathrm{~g} \cdot \mathrm{L}^{-1} \mathrm{CRF}$ may be sufficient for nodulated $S$. Xutahensis 'Torrey' to sustain acceptable visual quality and promote nodulation for $\mathrm{N}_{2}$ fixation with minimal nitrate leachate.

\section{Literature Cited}

Adams, C., J. Frantz, and B. Bugbee. 2013. Macroand micronutrient-release characteristics of three polymer-coated fertilizers: Theory and measurement. J. Plant Nutr. Soil Sci. 176:7688.

Beddes, T. and H.A. Kratsch. 2009. Seed germination of roundleaf buffaloberry (Shepherdia rotundifolia) and silver buffaloberry (Shepherdia argentea) in three substrates. J. Environ. Hort. 27:129-133.

Beddes, T. and H.A. Kratsch. 2010. Nodulation of seaside alder topdressed with controlledrelease fertilizer. HortTechnology 20:740-745.

Benson, D.R. and W.B. Silvester. 1993. Biology of Frankia strains, actinomycete symbionts of actinorhizal plants. Microbiol. Rev. 57:293319.

Bugbee, B. 2004. Nutrient management in recirculating hydroponic culture. Acta Hort. 648:99112.

Dawson, J.O. and J.C. Gordon. 1979. Nitrogen fixation in relation to photosynthesis in Alnus glutinosa. Bot. Gaz. 140:70-75.

Edmondson, J.L., Z.G. Davies, S.A. McCormack, K.J. Gaston, and J.R. Leake. 2011. Are soils in urban ecosystems compacted? A citywide analysis. Biol. Lett. 7:771-774.

Gordon, J.C. and C.T. Wheeler. 1987. Whole plant studies on photosynthesis and acetylene reduction in Alnus glutinosa. New Phytol. 80:179-186.

Glenn, J.S., C.H. Gilliam, J.H. Edwards, G.J. Keever, and P.R. Knight. 2000. Recycled waste paper mulch reduces available container N. J. Environ. Hort. 18:188-191.

Hooper, V.H., J. Endter-Wada, and C.W. Johnson. 2008. Theory and practice related to native plants: A case study of Utah landscape professionals. Landsc. J. 27:1-8.

Huss-Danell, K. 1997. Actinorhizal symbioses and their $\mathrm{N}_{2}$ fixation. New Phytol. 136:375-405.

Jeong, S.C. and D.D. Myrold. 2001. Population size and diversity of Frankia in soils of Ceanothus velutinus and Douglas-fir stands. Soil Biol. Biochem. 33:931-941.

Klooster, W.S., B.M. Cregg, R.T. Fernandez, and P. Nzokou. 2010. Growth and photosynthetic response of pot-in-pot-grown conifers to substrate and controlled-release fertilizer. HortScience 45:36-42.

Knowles, T.C., B.W. Hipp, and M.A. Hegemann. 1993. Container medium and slow-release nitrogen fertilizer influence growth and quality of Salvia farinacea. HortScience 28:623-625.

Kohls, S.J. and D.D. Baker. 1989. Effects of substrate nitrate concentration on symbiotic nodule formation in actinorhizal plants. Plant Soil 118:171-179.

Kratsch, H.A. and W.R. Graves. 2004. Nitrogen fixation as a stress-avoidance strategy among actinorhizal (non-legume) trees and shrubs. J. Crop Improv. 10:281-304.

Laws, M.T. and W.R. Graves. 2005. Nitrogen inhibits nodulation and reversibly suppresses nitrogen fixation in nodule of Alnus maritina. $\mathrm{J}$. Amer. Soc. Hort. Sci. 130:496-499.

Mee, W., J. Barnes, R. Kjelgren, R. Sutton, T. Cerny, and C. Johnson. 2003. Water wise: Native plants for intermountain landscapes. Utah State University Press, Logan, UT. 
Niemiera, A.X. and C.E. Leda. 1993. Nitrogen leaching from Osmocote-fertilized pine bark at leaching fractions of 0 to 0.4 . J. Environ. Hort. 11:75-77.

Norton, J. and Y. Ouyang. 2019. Controls and adaptive management of nitrification in agricultural soils. Front. Microbiol. 10:1931.

Parkinson, H., A. DeBolt, R. Rosentreter, and V. Geertson. 2003. Landscaping with native plants of the Intermountain Region. U.S. Bureau of Land Management, Boise, ID.

Poole, R.T. and C.A. Conover. 1989. Fertilization of four indoor foliage plants with Osmocote or Nutricote. J. Environ. Hort. 7:102-108.

Racette, S. and J.G. Torrey. 1989. Root nodule initiation in Gymnostoma (Casuarinaceae) and Shepherida (Elaeagnaceae) induced by Frankia strain HFPGpI1. Can. J. Bot. 67:2873-2879.

Righetti, T.L., C.H. Chard, and R.A. Backhaus. 1986. Soil and environmental factors related to nodulation in Cowania and Purshia. Plant Soil 91:147-160.

Schwencke, J. and M. Caru. 2001. Advances in actinorhizal symbiosis: Host pant-Frankia interactions, biology, and applications in arid land reclamation. A review. Arid Land Res. Manage. 154:283-327.

Sellstedt, A. and K. Huss-Danell. 1986. Biomass production and nitrogen utilization by Alnus incana when grown on $\mathrm{N}_{2}$ or $\mathrm{NH}_{4}^{+}$made available at the same rate. Planta 167:387-394.

Sriladda, C. 2011. Ecophysiology and genetic variation in domestication of shpaeralcea and shepherdia species for the Intermountain West. Utah State University, Logan, UT. 2 June 2020. $<$ https://digitalcommons.usu.edu/cgi/viewcontent .cgi? article $=2027 \&$ context $=$ etd $>$.

Sriladda, C., H.A. Kratsch, S.R. Larson, T.A. Monaco, F. Shen, and R.K. Kjelgren. 2016. Interspecific hybrid of xeric Shepherdia rotundifolia and riparian Shepherdia argentea: Description, and traits suitable for low-water urban landscapes. HortScience 51:822-828.

Sriladda, C., R. Kjelgren, H. Kratsch, T. Monaco, S. Larson, and F. Shen. 2014. Ecological adaptation of the endemic Shepherdia rotundifolia to conditions in its Colorado Plateau range. West. N. Amer. Nat. 74:79-91.

Taiz, L., E. Zeiger, I.M. Møller, and A. Murphy. 2015. Plant physiology and development. 6th ed. Sinauer Associates, Sunderland, MA.
Thomas, A.L. and D. Schrock. 2004. Performance of 67 native midwestern U.S. perennials in a low-maintenance landscape. HortTechnology 14:381-388.

Thomas, K.A. and A.M. Berry. 1989. Effects of continuous nitrogen application and nitrogen preconditioning on nodulation and growth of Ceanothus griseus var horizontalis. Plant Soil 118:181-187.

Tortosa, R.D. and M. Cusato. 1991. Effective nodulation of rhamnaceous actinorhizal plants induced by air dry soils. Plant Soil 131:229 233.

Urbano, C.C. 1989. The environmental debate: An industry issue. Amer. Nurseryman 169:69-73, 76-79, 81, 83, 85.

Valverde, C., A. Ferrai, and L.G. Wall. 2002. Phosphorus and the regulation of nodulation in the actinorhizal symbiosis between Discaria trinervis (Rhamnaceae) and Frankia BCU110501. New Phytol. 153:43-51.

Zhang, J., W. Wang, G. Sun, H. Liu, and X. Li. 2011. Photosynthesis of Hosta under light and controlled-release nitrogen fertilizer. Russ. J. Plant Physiol. 58:261-270. 